\title{
Effect of Necklace-Type Distribution of SiC Particles on Dry Sliding Wear Behavior of As-Cast AZ91D/SiC $p$ Composites
}

\author{
Chao Sun ${ }^{1}$, Nannan Lu ${ }^{2}$, Huan Liu ${ }^{1}{ }^{\circledR}$, Xiaojun Wang ${ }^{2, *}$, Xiaoshi $\mathrm{Hu}^{2}$ and Deqiang Chen ${ }^{3}$ \\ 1 College of Mechanics and Materials, Hohai University, Nanjing 210000, China; sunchao_239@163.com (C.S.); \\ liuhuanseu@hhu.edu.cn (H.L.) \\ 2 National Key Laboratory of Precision Hot Processing of Metal, Harbin Institute of Technology, \\ Harbin 150001, China; nnlu@stu.hit.edu.cn (N.L.); huxiaoshi@hit.edu.cn (X.H.) \\ 3 National United Engineering Laboratory for Advanced Bearing Tribology, Henan University of Science and \\ Technology, Luoyang 471000, China; dqchen@haust.edu.cn \\ * Correspondence: xjwang@hit.edu.cn
}

Received: 19 March 2020; Accepted: 10 April 2020; Published: 13 April 2020

check for updates

\begin{abstract}
In this study, the dry sliding wear behaviors of SiC particle reinforced AZ91D matrix composites fabricated by stirring casting method were systematically investigated. The $\mathrm{SiC}$ particles in as-cast composites exhibited typical necklace-type distribution, which caused the weak interface bonding between $\mathrm{SiC}$ particles and matrix in particle-segregated zones. During dry sliding at higher applied loads, $\mathrm{SiC}$ particles were easy to debond from the matrix, which accelerated the wear rates of the composites. While at the lower load of $10 \mathrm{~N}$, the presence of $\mathrm{SiC}$ particles improved the wear resistance. Moreover, the necklace-type distribution became more evident with the decrease of particle sizes and the increase of $\mathrm{SiC}$ volume fractions. Larger particles had better interface bonding with the matrix, which could delay the transition of wear mechanism from oxidation to delamination. Therefore, composites reinforced by larger $\mathrm{SiC}$ particles exhibited higher wear resistance. Similarly, owing to more weak interfaces in the composites with high content of $\mathrm{SiC}$ particles, more severe delamination occurred and the wear resistance of the composites was impaired.
\end{abstract}

Keywords: magnesium matrix composites; SiC particles; necklace distribution; wear mechanisms; wear rate

\section{Introduction}

The development and application of high-strength and light-weight metallic materials have received much attention in recent years owing to the increasing concerns of world environmental issues, such as air pollution, energy overconsumption, resource shortage, etc. Among various light-weight metallic materials, magnesium and its alloys exhibit great potential because of their low density, high specific strength and stiffness, good machinability, and so on, which were therefore considered as the next generation of green engineering structural materials [1-5]. Nevertheless, the absolute strength and elasticity modulus of magnesium alloys are relatively low, which could not meet the requirements of practical applications [6-9]. As a consequence, hard ceramic particles are always incorporated with magnesium alloys to fabricate magnesium matrix composites with improved mechanical properties [10-16].

Magnesium matrix composites were often produced by the stirring casting method due to its high production rate and low processing cost. Studies showed that the particulate reinforced magnesium matrix composites prepared by stirring casting often exhibited typical necklace-type distribution of particles [17-19]. That is to say, most particles were located at grain boundaries. At present, 
researches on magnesium matrix composites were mainly focused on their tensile mechanical properties, and little work reported the wear behavior of these magnesium matrix composites [20]. Since the magnesium matrix composites were usually adopted as automotive components, their wear behaviors were of vital importance to their operation performance and service life. Especially, the necklace distribution of reinforcement particles might significantly influence the wear behaviors of magnesium matrix composites.

So far, researches on wear behaviors of aluminum matrix composites have revealed that the volume fractions and sizes of reinforcements have evident impacts on the wear rates of $\mathrm{Al}$ matrix composites, and their influences sometimes are conflicting [21-31]. Generally, the wear rates of Al matrix composites decreased correspondingly with the increase of volume fraction of reinforcements [21-23]. While some researchers found that the wear rates of $\mathrm{Al}$ matrix composites increased as the increase of the reinforcement content [24]. The deterioration of the wear resistance was mainly ascribed to the breakage and pull-out of reinforcement, as well as the poor interfacial bonding between reinforcement and matrix. With regard to the particle size, contradiction also existed [25-30], which might be related to the transition of predominant wear mechanisms of composites facilitated by the change of particle sizes.

Based on above considerations, therefore, this study was aimed to investigate the effect of necklace particle distribution on the wear behavior of $\mathrm{SiC}$ particles $\left(\mathrm{SiC}_{\mathrm{p}}\right)$ reinforced $\mathrm{AZ91D}$ matrix $\left(\mathrm{SiC}_{\mathrm{p}} / \mathrm{AZ91D}\right)$ composites. Moreover, the influence of wear parameters of applied loads, as well as the volume fractions and sizes of $\mathrm{SiC}$ particles on the wear performance and wear mechanisms of the composites were also systematically discussed, which could provide an insight for future design and preparation of magnesium matrix composites.

\section{Experimental Details}

\subsection{Materials Preparation}

In this study, the AZ91D commercial magnesium alloy (with the composition of 9.29 wt $\% \mathrm{Al}$, $0.71 \mathrm{wt} \% \mathrm{Zn}$ and $0.23 \mathrm{wt} \% \mathrm{Mn}$ ) was employed as the metallic matrix, and three kinds of SiC particles with different average sizes of 5, 10 and $20 \mu \mathrm{m}$ were selected as the reinforcements. As tabulated in Table 1, five $\mathrm{SiC}_{\mathrm{p}} / \mathrm{AZ} 91$ composites with various sizes and volume fractions of $\mathrm{SiC}$ particles were designed for further investigation.

Table 1. The size and volume fraction of $\mathrm{SiC}$ particles in five designed composites.

\begin{tabular}{cccc}
\hline & $\mathbf{1 0 \%}$ & $\mathbf{1 5 \%}$ & $\mathbf{2 0 \%}$ \\
\hline $5 \mu \mathrm{m}$ & & $\sqrt{ }$ & \\
$10 \mu \mathrm{m}$ & $\sqrt{ }$ & $\sqrt{ }$ & $\sqrt{ }$ \\
$20 \mu \mathrm{m}$ & & $\sqrt{ }$ & \\
$\sqrt{- \text { the selection of particle size and volume fraction. }}$
\end{tabular}

Five $\mathrm{SiC}_{\mathrm{p}} / \mathrm{Mg}$ composites were fabricated by the semisolid stirring method. First, the AZ91D alloy was melted at $993 \mathrm{~K}$, and cooled to $853 \mathrm{~K}$ in order to maintain the semi-solid status. The SiC particles were preheated at $873 \mathrm{~K}$ and then added into the semi-solid melt. To ensure the distribution of $\mathrm{SiC}$ particles, the melt was stirred at $853 \mathrm{~K}$ at the stirring rate of $800 \sim 1200 \mathrm{r} / \mathrm{min}$ under the protection of mixed atmosphere of $\mathrm{CO}_{2}$ and $\mathrm{SF}_{6}$. After stirred for $15 \mathrm{~min}$, the mixed melt was reheated to $993 \mathrm{~K}$ rapidly, and finally the mixture was poured into a preheated steel mould $(623 \mathrm{~K})$, which allowed the melt to solidify under a pressure of $100 \mathrm{MPa}$ to obtain a compact composite ingot without porosity.

\subsection{Wear Testing}

To access the wear behaviors of AZ91D alloy and $\mathrm{SiC}_{\mathrm{p}}$ /AZ91D composites, dry sliding wear tests were performed on a pin-on-disc apparatus (UMT produced by Bruker, Karlsruhe, Germany) 
at room temperature under various wear conditions. The applied loads were set as $10 \mathrm{~N}, 20 \mathrm{~N}$ and $30 \mathrm{~N}$, respectively. The sliding velocity and sliding distance were set as constants of $0.8 \mathrm{~m} / \mathrm{s}$ and one kilometer. The pins specimens with diameter of $6.2 \mathrm{mM}$ and length of $20.4 \mathrm{mM}$ were machined from the as-cast alloy and composites. Then the contact surfaces of all pins were grinded by the 2000 and 4000-grit silicon carbide papers to ensure an uniform roughness. The counterpart used in wear tests was oil-hardened GCr15 bearing steel with hardness of $65 \mathrm{HRC}$, and its detailed composition was C: $0.95-1.05$ wt \%, Mn: 0.20-0.40 wt \%, Si: 0.15-0.35 wt \%, Cr: $1.30-1.65$ wt \%, S: $\leq 0.02$ wt \%, $\mathrm{P}: \leq 0.027 \mathrm{wt} \%, \mathrm{Ni}: \leq 0.30 \mathrm{wt} \%, \mathrm{Cu}: \leq 0.30 \mathrm{wt} \%$ and Mo: $\leq 0.30 \mathrm{wt} \%$. The counterpart discs were machined to $60 \mathrm{mM}$ in diameter and $5 \mathrm{mM}$ in thickness, and then polished with the same silicon carbide papers. Moreover, all specimens and discs were degreased with acetone before testing. After each test, the pins were weighted by the electronic balance to determine the weight loss. The volume loses were transformed from weight loss by the density which based upon Archimedes' principle. volume wear rate $\left(\dot{W}_{1}\right)$ was calculated by the Equation (1):

$$
\dot{W}_{1}=V / S
$$

where $V$ is volume loses $\left(\mathrm{mm}^{3}\right)$ and $S$ is sliding distance (m). $V$ was determined by the weight loss and density of the composites.

The standard Brinell tester was employed to evaluate the hardness of alloy and composites. The Instron 1186 electronic universal testing machine was used to assess the tensile mechanical properties of as-cast AZ91D alloy and five composites at a constant cross-head speed of $0.5 \mathrm{mM} / \mathrm{min}$. Optical microscope $(\mathrm{OM})$ and scanning electron microscope (SEM) were applied to observe the microstructure of the composites. In addition, the worn surfaces of the pins and wear debris collected after testing were also examined and analyzed by using the scanning electron microscopy (SEM) and energy dispersive $\mathrm{X}$-ray spectroscopy (EDS).

\section{Results and Discussion}

\subsection{Microstructure and Mechanical Properties of the Composites}

Figure 1 shows the optical micrographs of as-cast AZ91D alloy and five composites. The gray contrast in the images corresponds to $\alpha$-Mg matrix, while the dark contrast shows the existence of second phases $\left(\mathrm{Mg}_{17} \mathrm{Al}_{12}\right.$ and $\left.\mathrm{SiC}\right)$. The $\mathrm{SiC}$ particles usually exhibit granular shape with sharp edges. It is apparent from Figure 1 that the $\mathrm{SiC}$ particles were mainly located at grain boundaries, and this distribution pattern was called necklace-type, which was typical for the metal matrix composites fabricated by stir casting method $[17,19]$. Roughly estimation demonstrated that the sizes and volume fractions of $\mathrm{SiC}$ particles in the images are in good agreement with experimental design. Moreover, it can be seen that $\mathrm{SiC}$ particles with finer sizes (compared with Figure $1 \mathrm{~b}, \mathrm{~d}, \mathrm{f}$ ) and higher volume fractions (compared with Figure 1c-e) were more inclined to be aggregated at grain boundaries, namely, much easier to form necklace-type distribution. It has been reported that this necklace-type distribution of reinforcements significantly affected the mechanical properties and fracture behaviors of the composites [19], which may also exert an important impact on the wear behavior of the composites.

Table 2 lists the mechanical properties and density values of AZ91D alloy and five composites. Generally, the variation of modulus, ductility and density values of the composites exhibited no obvious correlations with the change of sizes and volume fractions of $\mathrm{SiC}$ particles. The ultimate tensile strength of the composites increased with the increase of volume fractions, as well as the sizes of SiC particles. This was mainly due to the necklace-type distribution of SiC particles. As shown in Figure 1, the necklace-type particle distribution became more evident with the decrease of particle sizes. It is universally known that this distribution caused weak interface bonding between $\mathrm{SiC}$ particles and the matrix [17-19]. Consequently, composites reinforced by larger particles had better interface bonding between particles and the matrix. With regard to the Brinell hardness of the composites, however, finer $\mathrm{SiC}_{\mathrm{p}}$ contributed to the improvement of hardness, which was different with the variation of 
strength. This may be attributed to different coefficient of thermal expansion (CTE) and the content of dislocations [31].
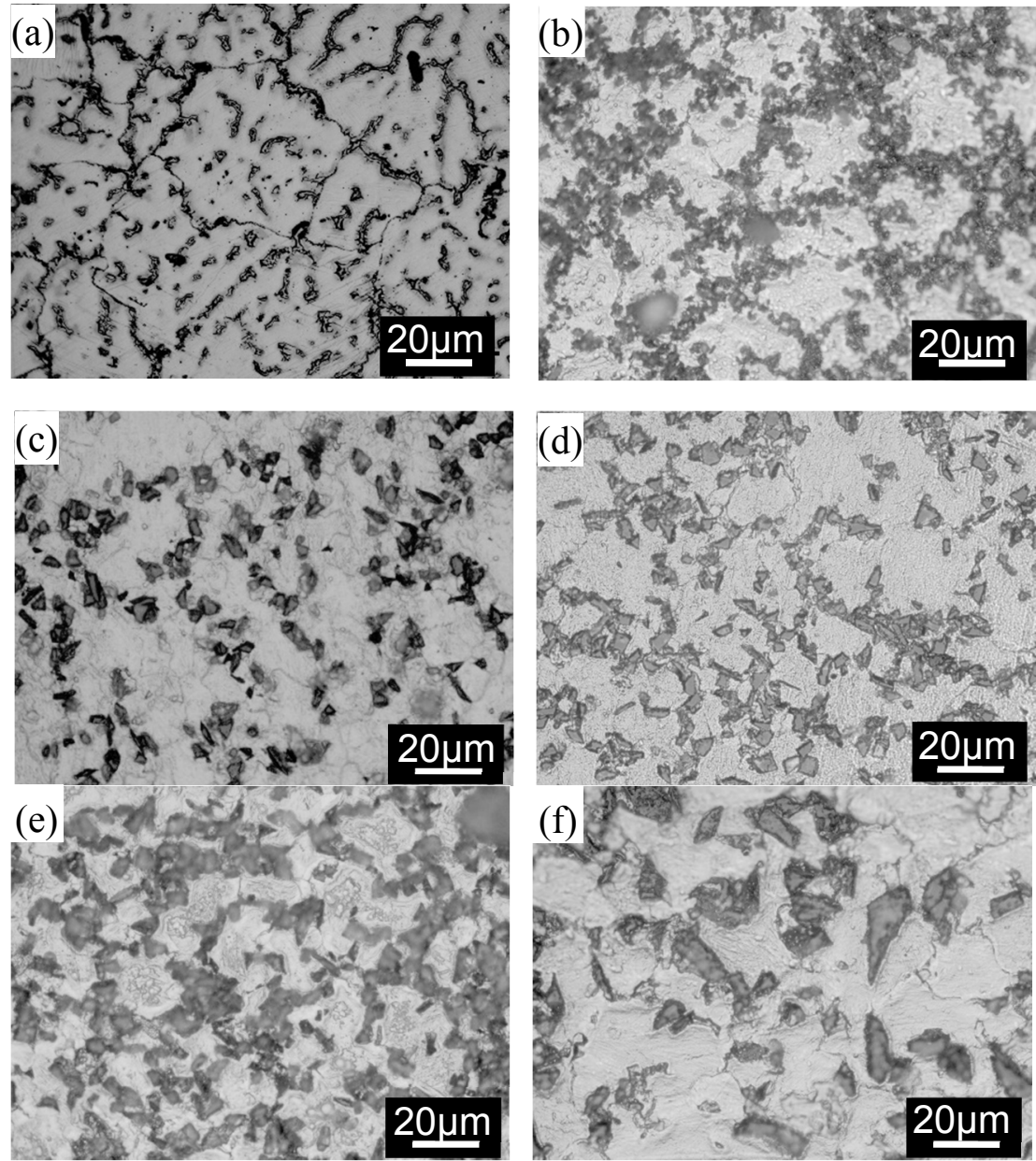

Figure 1. Optical micrographs of as-cast alloy and composites: (a) AZ91D, (b) $5 \mu \mathrm{m} 15 \mathrm{vol} \%$ composite, (c) $10 \mu \mathrm{m} 10 \mathrm{vol} \%$ composite, (d) $10 \mu \mathrm{m} 15 \mathrm{vol} \%$ composite, (e) $10 \mu \mathrm{m} 20 \mathrm{vol} \%$ composite, and (f) $20 \mu \mathrm{m}$ $15 \mathrm{vol} \%$ composites.

Table 2. Mechanical properties and density values of as-cast AZ91D alloy and five composites.

\begin{tabular}{|c|c|c|c|c|c|c|}
\hline Materials & $\begin{array}{c}\text { Ultimate } \\
\text { Tensile } \\
\text { Strength } \\
\text { (MPa) }\end{array}$ & $\begin{array}{l}\text { Tensile } \\
\text { Yield } \\
\text { Strength } \\
\text { (MPa) }\end{array}$ & $\begin{array}{l}\text { Elastic } \\
\text { Modulus } \\
\text { (GPa) }\end{array}$ & $\begin{array}{c}\text { Ductility (\% } \\
\text { EL) }\end{array}$ & $\begin{array}{l}\text { Hardness } \\
\text { (HB) }\end{array}$ & $\begin{array}{l}\text { Density } \\
\left(\mathrm{g} / \mathrm{cm}^{3}\right)\end{array}$ \\
\hline AZ91D & 144.3 & 86.3 & 48.8 & 2.3 & 73.2 & 1.801 \\
\hline $5 \mu \mathrm{m} 15 \% \mathrm{SiC}_{\mathrm{p}} / \mathrm{Mg}$ & 150.6 & 50.4 & 74.2 & 0.2 & 112.0 & 2.006 \\
\hline $10 \mu \mathrm{m} 10 \% \mathrm{SiC}_{\mathrm{p}} / \mathrm{Mg}$ & 151.2 & 109.6 & 53.8 & 1.3 & 76.3 & 1.914 \\
\hline $10 \mu \mathrm{m} 15 \% \mathrm{SiC}_{\mathrm{p}} / \mathrm{Mg}$ & 175.4 & 164.4 & 49.3 & 0.6 & 93.8 & 1.997 \\
\hline $10 \mu \mathrm{m} 20 \% \mathrm{SiC}_{\mathrm{p}} / \mathrm{Mg}$ & 213.6 & 209.3 & 65.0 & 0.5 & 106.0 & 2.084 \\
\hline $20 \mu \mathrm{m} 15 \% \mathrm{SiC}_{\mathrm{p}} / \mathrm{Mg}$ & 179.8 & 150.7 & 69.0 & 0.7 & 84.9 & 1.998 \\
\hline
\end{tabular}

\subsection{Effect of Applied Loads on Wear Behavior of the Composites}

Figure 2 shows that the variations of wear rate of the AZ91 alloy and $10 \mu \mathrm{m} 15 \mathrm{vol} \%$ composite tested under the loads of 10,20 and $30 \mathrm{~N}$ at a constant sliding speed of $0.8 \mathrm{~m} / \mathrm{s}$. It can be seen that both the wear rates of AZ91 alloy and composites increased with the increase of applied loads. The wear rate of the composites was much lower than that of matrix alloy at the load of $10 \mathrm{~N}$, but it increased rapidly and became slightly higher than the alloy at the loads of $20 \mathrm{~N}$ and $30 \mathrm{~N}$. This was similar to the 
results of Lim et al. [32], who claimed that the wear resistance of composites had slight improvement at the lower load of $10 \mathrm{~N}$. Alpas et al. [33,34] also reported that the wear rate of the $\mathrm{SiC}_{\mathrm{p}} / \mathrm{A} 356 \mathrm{Al}$ matrix composite was lower than that of the alloy at lower load, and then it became similar to the matrix at higher load. Based on above results, it can be concluded that the addition of $\mathrm{SiC}_{\mathrm{p}}$ could promote the wear resistance of the composite at the lower load.

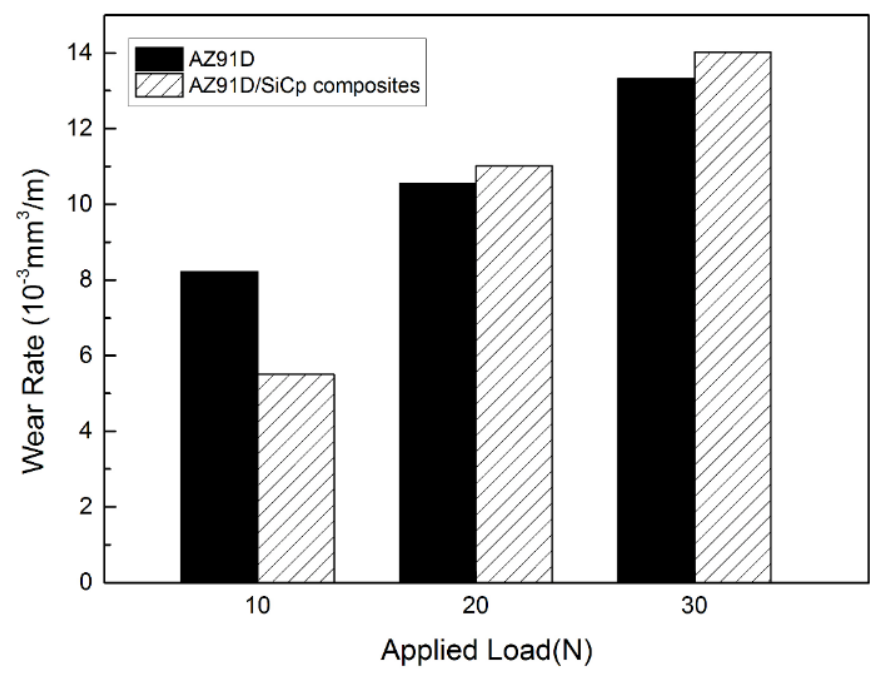

Figure 2. Effect of applied loads on ware rates of the AZ91D alloy and $10 \mu \mathrm{m} 15 \mathrm{vol} \%$ composite at the constant sliding speed of $0.8 \mathrm{~m} / \mathrm{s}$.

Figure 3 shows the worn surfaces of the pin samples after tested at different applied loads. At the lower load, the grooves evidently parallel to the sliding direction were observed (Figure 3a). The grooves were typical feature of abrasion mechanism, which were usually caused by the hard asperities on the steel counterface or the hard particles between the wear interfaces. The hard particles cut or plough the soft sample surface, resulting in the formation of small fragments or thin band-like debris [35]. As shown in Figure 4, the ribbon debris were observed after worn at the load of $10 \mathrm{~N}$, which further confirmed the cutting or ploughing action by the abrasive particles occurred during wear test. In addition, the digital image processing method has been widely employed recently to evaluate the damage process of metallic materials with the help of artificial markers [36]. It seems that the wear lines on the worn surfaces might be regarded as markers to quantitatively assess or compare the wear behaviors, and we would consider this point in the future.
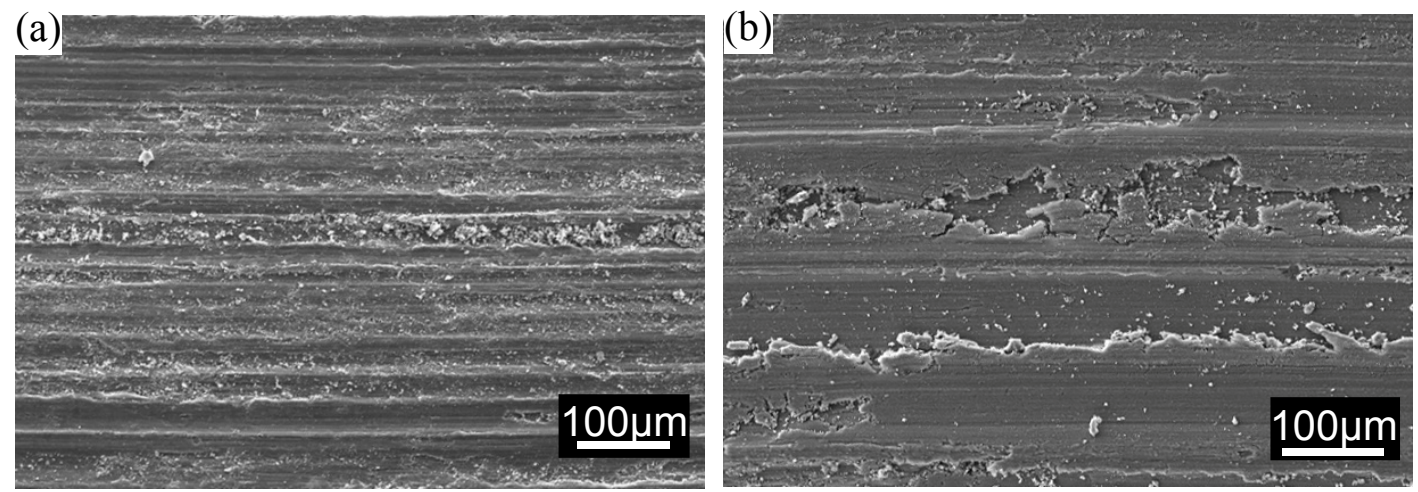

Figure 3. Cont. 

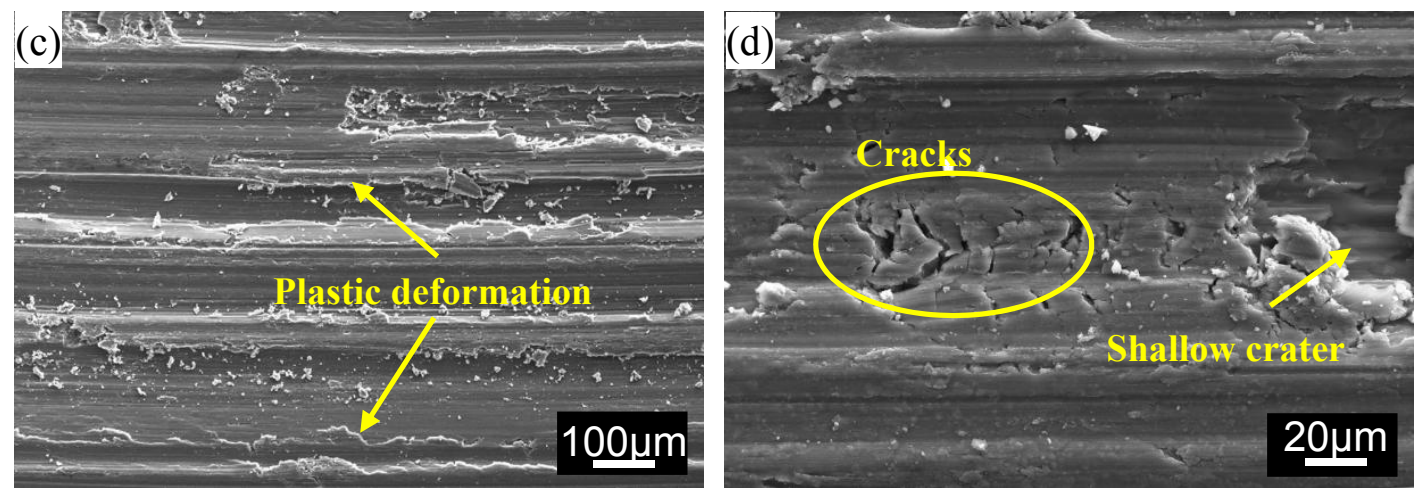

Figure 3. SEM images of worn surfaces of the $10 \mu \mathrm{m} 15 \mathrm{vol} \%$ composite tested at the load of (a) 10, (b) 20, and (c,d) $30 \mathrm{~N}$ at a sliding speed of $0.8 \mathrm{~m} / \mathrm{s}$.

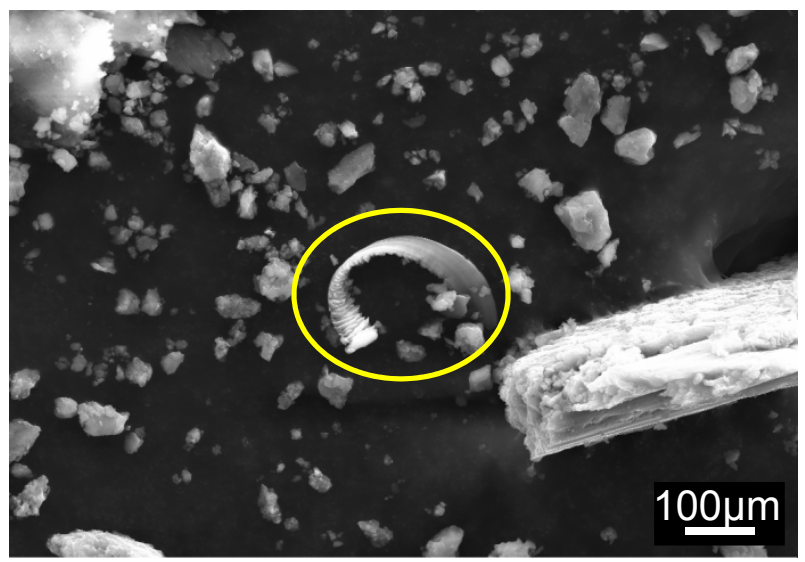

Figure 4. Magnesium ribbon observed in the wear debris of $10 \mu \mathrm{m} 15 \mathrm{vol} \%$ composite after worn at the load of $10 \mathrm{~N}$ at the sliding speed of $0.8 \mathrm{~m} / \mathrm{s}$.

At higher load, the features of worn surfaces and debris changed (Figure $3 b, c)$. The trace of severe plastic deformation was found on the worn surface (marked by arrows in Figure 3c) at high load of 30 N. Moreover, a few cracks and the shallow craters were also observed on the worn surface at high magnification (Figure 3d). As shown in Figure 5a, the wear debris of the composite tested at $30 \mathrm{~N}$ were mainly sheet-like, which were the typical feature of delamination $[37,38]$. Thus, delamination wear may become the main wear mechanism of the composites at the load of $30 \mathrm{~N}$.
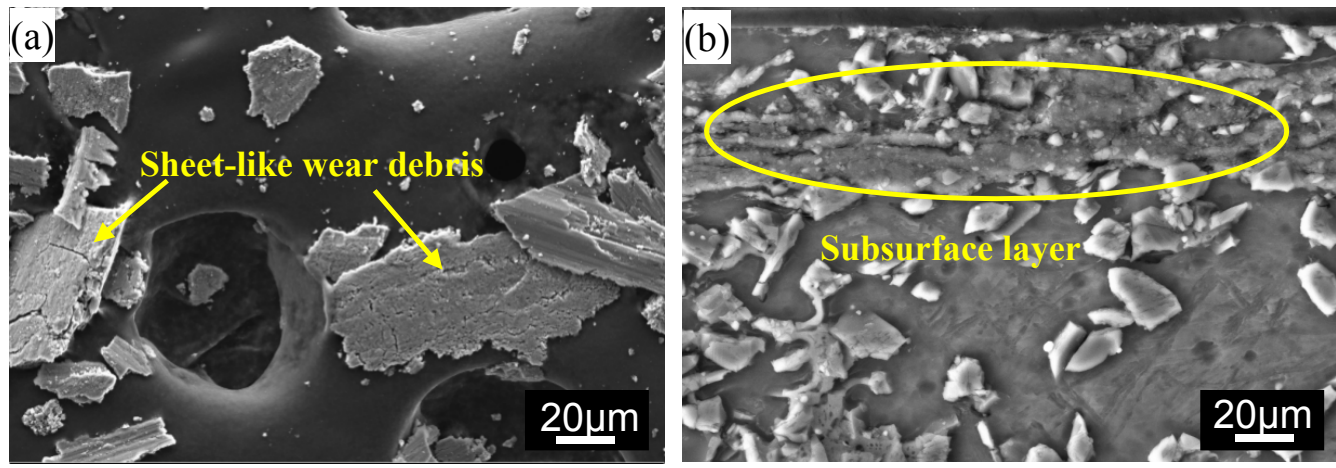

Figure 5. SEM images of the $10 \mu \mathrm{m} 15 \mathrm{vol} \%$ composite tested at load of $30 \mathrm{~N}$ at a sliding speed of $0.8 \mathrm{~m} / \mathrm{s}$ : (a) sheet-like wear debris of delamination, and (b) cross-section of worn surface.

In addition, Figure $5 b$ shows the cross-section of the worn surface. During dry sliding, the worn surfaces bore plastic deformation. In the present composite, the necklace-type distribution of particles 
resulted in weak interface bonding. Therefore, many cracks initiated through particle debonding in the particle-segregated zones, as shown in the subsurface layer of Figure 5b. The crack propagation resulted in the cross cracks, then the sheet-like debris was formed through the further growth of the cross cracks. Meantime, the shallow crater could also be formed due to the separation of the sheet-like debris from worn surface.

\subsection{Effect of Particle Size on Wear Behavior of the Composites}

Figure 6 shows the influence of particle size on the wear rate of composites with $15 \mathrm{vol} \% \mathrm{SiC}$ particles tested at the applied load of $20 \mathrm{~N}$ and sliding speed of $0.8 \mathrm{~m} / \mathrm{s}$. Although the wear rates of composites with $5 \mu \mathrm{m}$ and $10 \mu \mathrm{m} \mathrm{SiC} \mathrm{particles} \mathrm{were} \mathrm{higher} \mathrm{than} \mathrm{AZ91D} \mathrm{alloy,} \mathrm{the} \mathrm{wear} \mathrm{rates} \mathrm{of}$ the composites decreased with the increase of particle sizes, and the wear rate of the $20 \mu \mathrm{m} 15 \mathrm{vol} \%$ composite was about half of that for the alloy. This phenomenon implied that the wear mechanisms might be different for the composites with different $\mathrm{SiC}$ particle sizes.

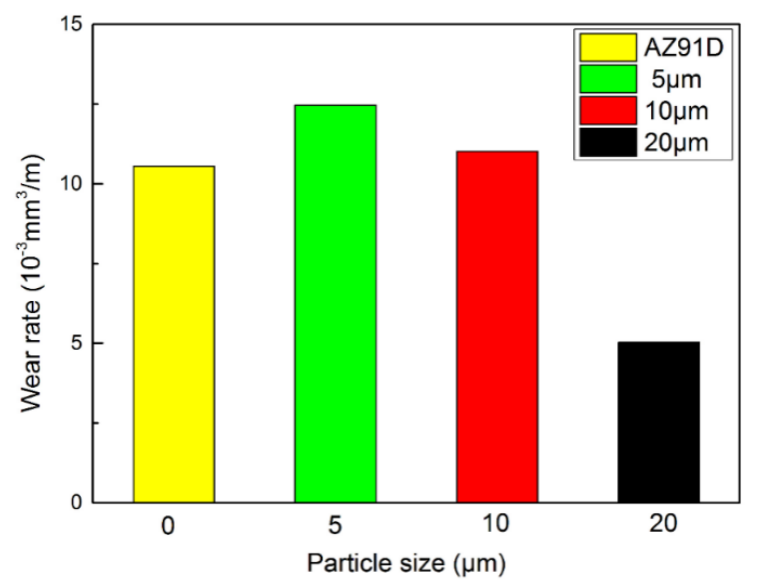

Figure 6. Effect of particle size on the wear rate of the $15 \%$ composites at the load of $20 \mathrm{~N}$ and sliding speed $0.8 \mathrm{~m} / \mathrm{s}$.

Figure 7 shows the morphology of worn surface of the $20 \mu \mathrm{m} \mathrm{SiC} / \mathrm{AZ91}$ composite, and abundant fine granular debris was observed. As shown in Figure $7 \mathrm{~b}$, the average size of the fine granular debris was estimated to be about $5 \mu \mathrm{m}$. Moreover, the EDS result of the debris shown in Figure 7c displayed strong $\mathrm{Mg}$ and $\mathrm{O}$ peaks, suggesting the existence of magnesium oxides $(\mathrm{MgO})$. These characteristics revealed that oxidative wear occurred during sliding [32,39]. Figure 8 shows the worn surface of AZ91D alloy tested at the same condition, and only a little fine debris was observed, which indicated that the extent of oxidation wear for the test of AZ91D was much slighter than that of the $20 \mu \mathrm{m}$ composite. Since these fine debris could serve as the lubricant during the dry sliding [33], which should be the reason for the low wear rate of $20 \mu \mathrm{m}$ composite.
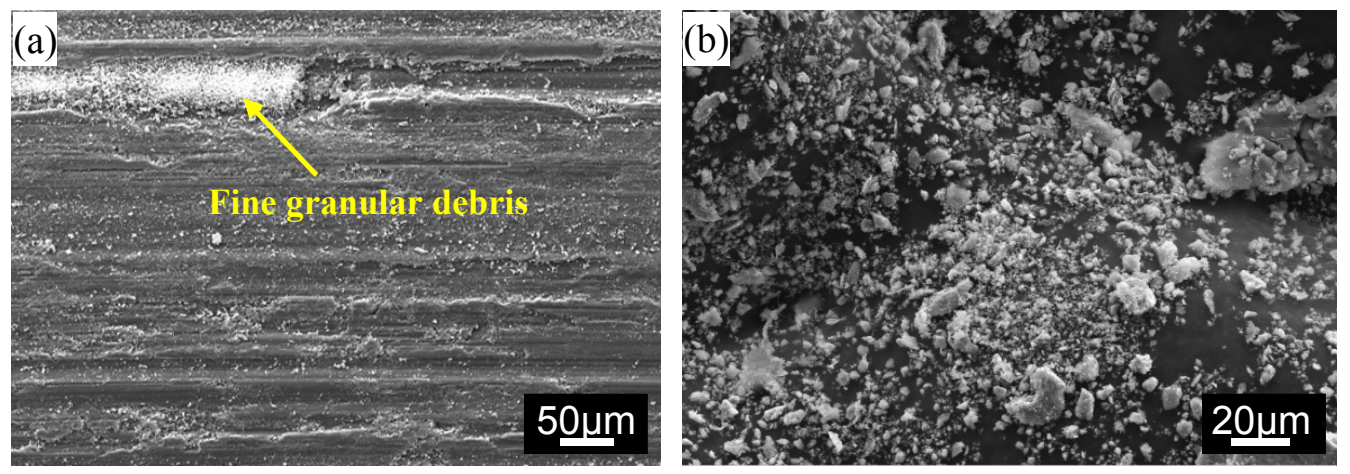

Figure 7. Cont. 


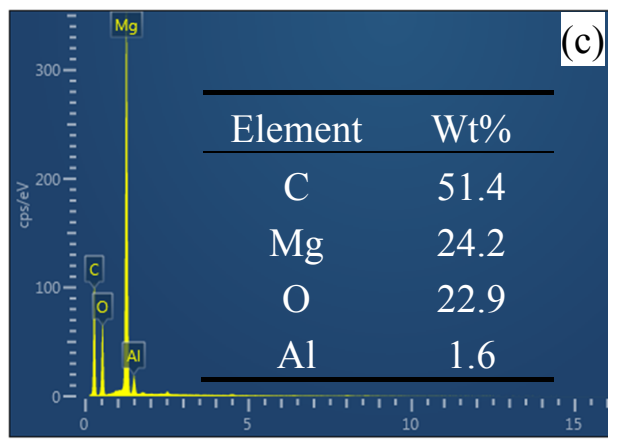

Figure 7. SEM images of the $20 \mu \mathrm{m} 15 \mathrm{vol} \%$ composite after wear test: (a) the pin worn surface, (b) the wear debris, and (c) corresponding EDS result of the fine granular debris.

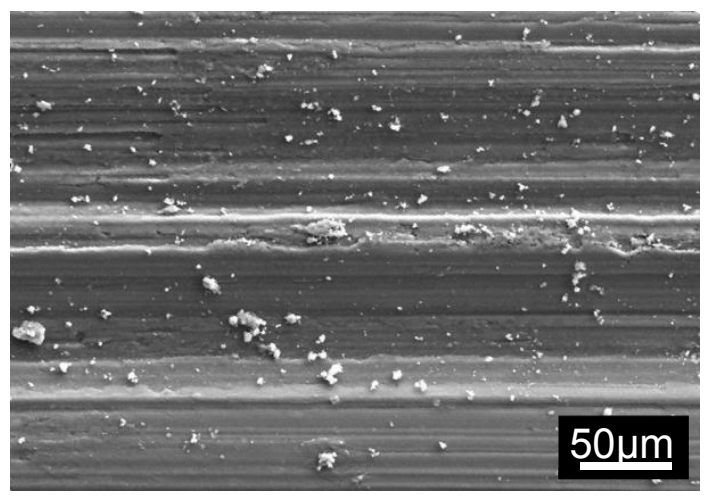

Figure 8. SEM image of the worn surface of AZ91D pin.

Figure 9 illustrates the SEM images of worn surfaces and debris of AZ91D alloy and three $15 \mathrm{vol} \%$ composites with different $\mathrm{SiC}$ sizes. As shown in Figure 9b, a lot of flake-like wear debris and little fine granular wear debris were observed for $5 \mu \mathrm{m}$ composites, which was very different from the $20 \mu \mathrm{m}$ composite. These features obviously revealed that the main wear mechanism for the $5 \mu \mathrm{m}$ composites was delamination. Moreover, compared with the wear debris of different composites in Figure 9, it can be seen that with the increase of $\mathrm{SiC}$ particle size, the number of sheet-like debris decreased, while the amount of fine granular debris obviously increased, suggesting the dominated wear mechanisms might be changed from delamination to oxidation.

As shown in Figure 1, the particles were mainly distributed at grain boundaries (necklace-type) within the composites. In addition, the necklace-type distribution became more evident with the decrease of particle sizes. There might be more cracks within the composites reinforced by smaller particles. As a consequence, larger particles offer higher load-bearing capacity than smaller particles in present composites, and the finest $\mathrm{SiC}$ particles $(5 \mu \mathrm{m})$ were easy to debond form matrix during sliding, forming abundant flak-like debris by delamination. Similar results were also observed in Al matrix composites [27,40,41]. Chung and Hwang et al. [27] studied the wear behavior of $\mathrm{SiC}_{\mathrm{p}} / \mathrm{Al}$ composites and pointed out that mMCs containing coarser particles exhibited higher wear resistance as compared with mMCs containing the finer particles with the constant volume fraction of $\mathrm{SiC}_{\mathrm{p}}$. 

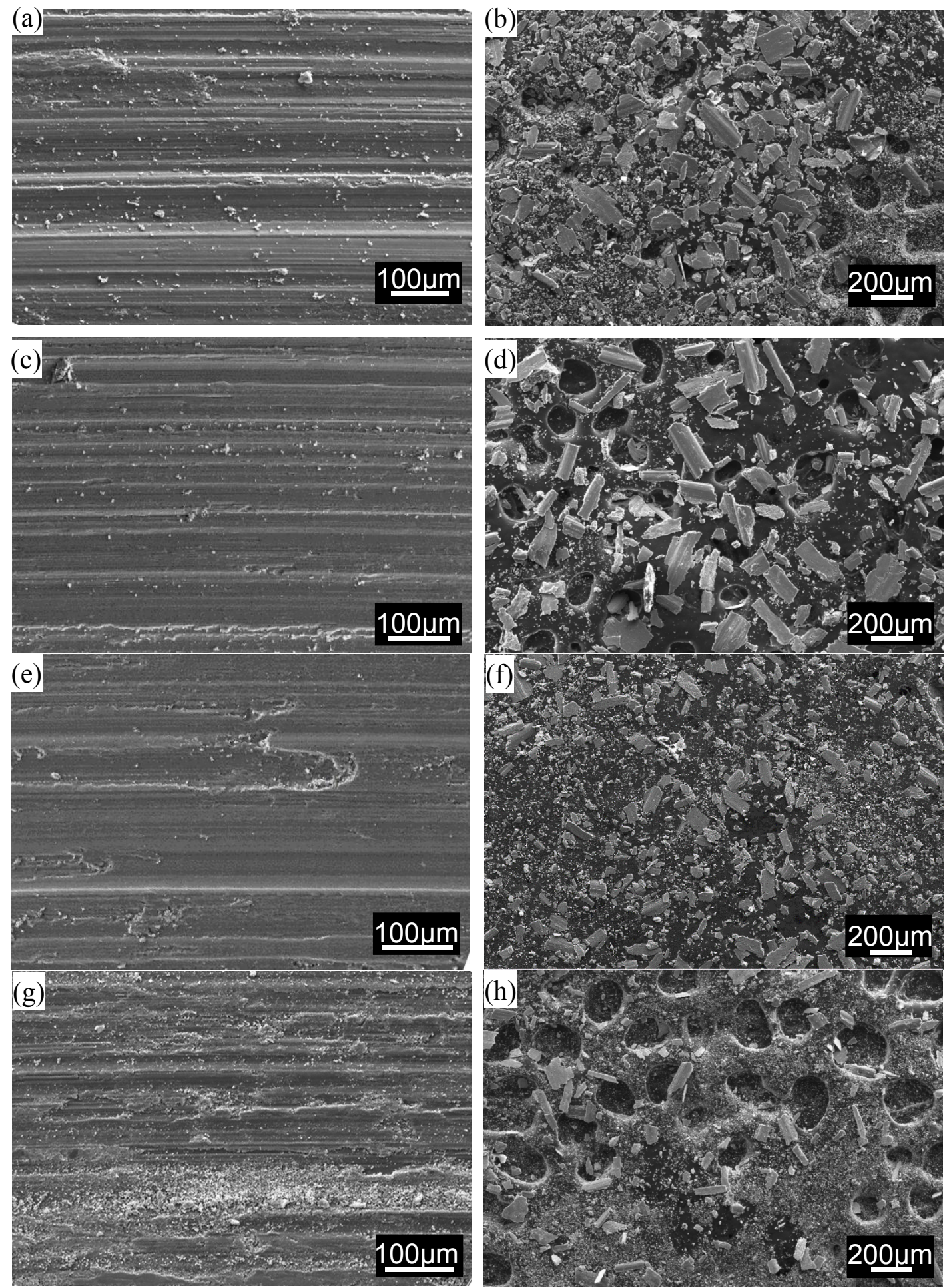

Figure 9. The morphology of $(\mathbf{a}, \mathbf{c}, \mathbf{e}, \mathbf{g})$ worn surfaces, and $(\mathbf{b}, \mathbf{d}, \mathbf{f}, \mathbf{h})$ wear debris of $(\mathbf{a}, \mathbf{b})$ as-cast AZ91D alloy, (c,d) $5 \mu \mathrm{m} 15 \mathrm{vol} \%$ composite, (e,f) $10 \mu \mathrm{m} 15 \mathrm{vol} \%$ composite, and (g,h) $20 \mu \mathrm{m} 15 \mathrm{vol} \%$ composite tested the load $20 \mathrm{~N}$ and sliding speed $0.8 \mathrm{~m} / \mathrm{s}$.

\subsection{Effect of Particle volume Fraction on Wear Behavior of the Composites}

Figure 10 shows the influence of volume fraction of $\mathrm{SiC}$ particles on the wear rate of $10 \mu \mathrm{m}$ composites tested at the load of $20 \mathrm{~N}$ and sliding speed of $0.8 \mathrm{~m} / \mathrm{s}$. The wear rate of the composites increased slightly as the content of $\mathrm{SiC}$ particles increased from 10 to $15 \mathrm{vol} \%$, which could be attributed to the same dominated wear mechanisms. Compared with the worn surfaces and debris shown in 
Figures $9 \mathrm{c}$ and 11 , it can be concluded that both oxidation and delamination were the dominated wear mechanisms for the 10 and $15 \mathrm{vol} \%$ composites, while the dominated wear mechanism for the $20 \mathrm{vol} \%$ composite was delamination. As the content of SiC particles increased, the amount of sheet-like debris increased evidently, indicating the delamination became more severe. Moreover, the wear rate increased evidently when the volume fraction of $\mathrm{SiC}$ particles reached to $20 \mathrm{vol} \%$. This result was different from that observed in $\mathrm{Al}$ matrix composites. It is widely reported that the wear rates of $\mathrm{Al}$ matrix composites decreased with the increase of volume fraction of reinforcements [42-46]. This difference may be caused by the typical particle distribution formed in the present composite.

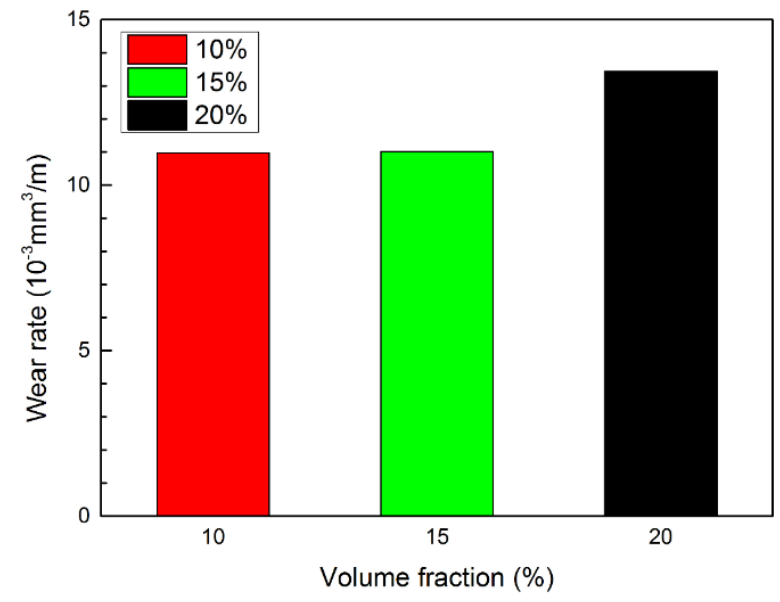

Figure 10. Effect of volume fraction of $\mathrm{SiC}$ particles on the ware rate of the $10 \mu \mathrm{m}$ composites tested at the load of $20 \mathrm{~N}$ and sliding speed of $0.8 \mathrm{~m} / \mathrm{s}$.
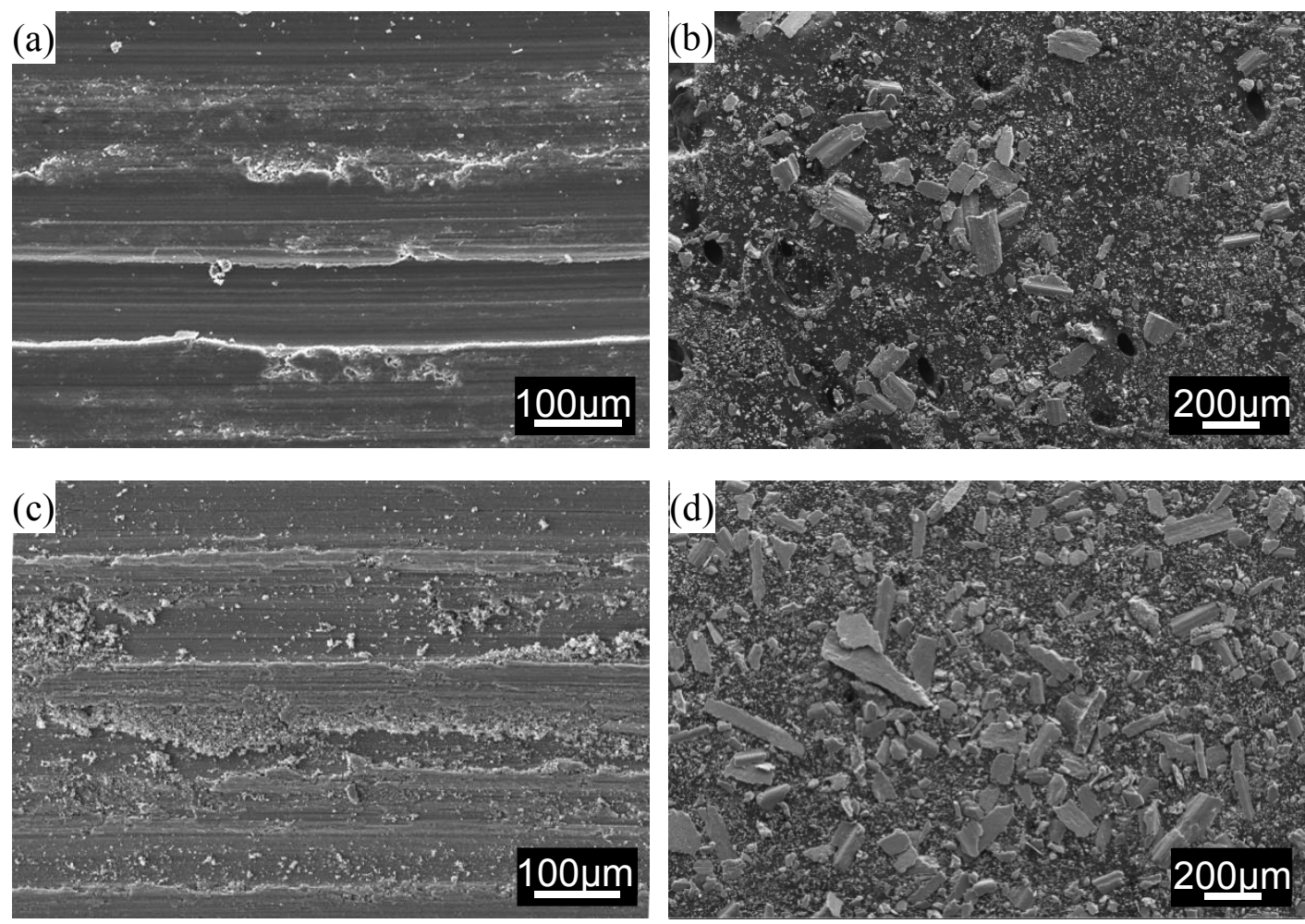

Figure 11. SEM images of $(\mathbf{a}, \mathbf{c})$ worn surfaces, and $(\mathbf{b}, \mathbf{d})$ wear debris for the $(\mathbf{a}, \mathbf{b}) 10 \mu \mathrm{m} 10 \mathrm{vol} \%$ composite, and (c,d) $10 \mu \mathrm{m} 20 \mathrm{vol} \%$ composites tested at the load of $20 \mathrm{~N}$ and sliding speed of $0.8 \mathrm{~m} / \mathrm{s}$. 
As mentioned above, the necklace particle distribution became more obvious with the increase of $\mathrm{SiC}_{\mathrm{p}}$ contents. The particles segregation was more severe in the $20 \mathrm{vol} \%$ composite, as shown in Figure 1, which suggests that there were more weak interfaces in the $20 \mathrm{vol} \%$ composite. As the stress caused by dry sliding was easy to exceed the strength of weak interfaces, there were more $\mathrm{SiC}$ particles debonded from the matrix. Shown in Figure 12, the SiC particles were found in the wear debris of the $20 \mathrm{vol} \%$ composite, and EDS results indicated the particle was silicon carbide (SiC). The detection of $\mathrm{SiC}$ particles further demonstrated that more severe delamination occurred in the $20 \mathrm{vol} \%$ composite. Furthermore, the $\mathrm{SiC}_{\mathrm{p}}$ in the debris may also facilitate the three-body abrasive wear during sliding [46], which can aggravate the wear extent of the composite.
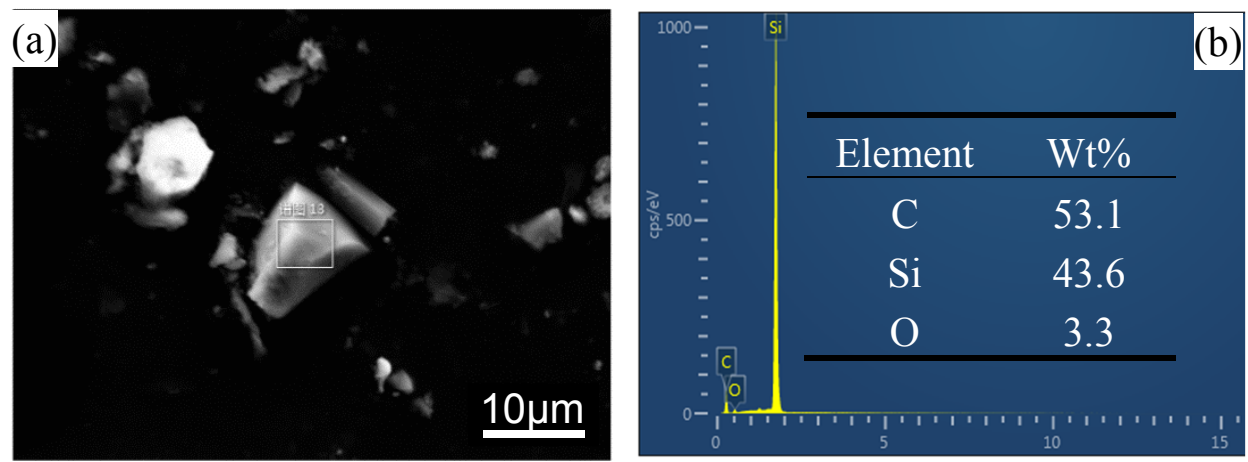

Figure 12. (a) SEM image of the SiC particles from the wear debris of $10 \mu \mathrm{m} 20 \mathrm{vol} \%$ composite tested at the load of $20 \mathrm{~N}$ and sliding speed of $0.8 \mathrm{~m} / \mathrm{s}$, and (b) the corresponding EDS result of the particle.

\subsection{Wear Mechanisms of the Composites with Necklace-Type Distribution}

Based on above SEM examinations of the worn surfaces and wear debris, three main wear mechanism can be identified for the composites with various contents and sizes of SiC particles under different sliding conditions, either singly or in combination. These mechanisms include abrasion, oxidation, and delamination. A detailed summary of the wear mechanisms for each composites tested at the load of $20 \mathrm{~N}$ and sliding speed of $0.8 \mathrm{~m} / \mathrm{s}$ is presented in Table 3. In the following sections, we mainly discussed the relationship between wear mechanisms and worn surfaces (debris) to better understand the influence of sliding conditions, volume fractions and sizes of SiC particles on wear behavior of the composites with typical necklace-type distribution.

Table 3. The summarized wear features and wear mechanisms for $A Z 91 \mathrm{D}$ alloy and various $\mathrm{SiC}_{\mathrm{p}} / \mathrm{AZ91D}$ composites tested at the load of $20 \mathrm{~N}$ and sliding speed of $0.8 \mathrm{~m} / \mathrm{s}$.

\begin{tabular}{|c|c|c|c|c|c|c|c|c|}
\hline \multirow{3}{*}{ Material } & \multirow{3}{*}{$\begin{array}{c}\text { Wear Rate } \\
\left(10^{-3} \mathrm{mM}^{3} / \mathrm{m}\right)\end{array}$} & \multirow{3}{*}{$\begin{array}{c}\text { Friction } \\
\text { Coefficient }\end{array}$} & \multicolumn{3}{|c|}{ Features } & \multirow{2}{*}{\multicolumn{3}{|c|}{ Wear Mechanisms ${ }^{1}$}} \\
\hline & & & \multirow{2}{*}{$\begin{array}{c}\begin{array}{c}\text { Worn } \\
\text { Surface }\end{array} \\
\text { Grooves }\end{array}$} & \multicolumn{2}{|c|}{ Wear Debris } & & & \\
\hline & & & & $\begin{array}{c}\text { Fine } \\
\text { Particles }\end{array}$ & Sheets & Abr & Oxi & Del \\
\hline Matrix & 10.7 & 0.32 & $\sqrt{ } \sqrt{ }^{2}$ & $\sqrt{ } \sqrt{ }$ & $\sqrt{ } \sqrt{ }$ & $\sqrt{ } \sqrt{ }$ & $\sqrt{ } \sqrt{ }$ & $\sqrt{ } \sqrt{ }$ \\
\hline $\begin{array}{c}5 \mu \mathrm{m} 15 \mathrm{vol} \% \\
\text { composite }\end{array}$ & 12.5 & 0.39 & $\sqrt{ }$ & $\sqrt{ }$ & $\sqrt{ } \sqrt{ }$ & $\sqrt{ }$ & $\sqrt{ }$ & $\sqrt{ } \sqrt{ }$ \\
\hline $\begin{array}{c}10 \mu \mathrm{m} 15 \mathrm{vol} \% \\
\text { composite }(10 \mathrm{~N})^{3}\end{array}$ & 5.5 & 0.52 & $\sqrt{ } \sqrt{ }$ & $\sqrt{ } \sqrt{ }$ & $\sqrt{ }$ & $\sqrt{ } \sqrt{ }$ & $\sqrt{ } \sqrt{ }$ & $\sqrt{ }$ \\
\hline $\begin{array}{c}10 \mu \mathrm{m} 15 \mathrm{vol} \% \\
\text { composite }\end{array}$ & 11.0 & 0.43 & $\sqrt{ }$ & $\sqrt{ } \sqrt{ }$ & $\sqrt{ } \sqrt{ }$ & $\sqrt{ }$ & $\sqrt{ } \sqrt{ }$ & $\sqrt{ } \sqrt{ }$ \\
\hline $\begin{array}{c}10 \mu \mathrm{m} 15 \mathrm{vol} \% \\
\text { composite (30N) }\end{array}$ & 14.0 & 0.39 & $\sqrt{ }$ & $\sqrt{ }$ & $\sqrt{ } \sqrt{ }$ & $\sqrt{ }$ & $\sqrt{ }$ & $\sqrt{ } \sqrt{ } \sqrt{ }$ \\
\hline $\begin{array}{c}20 \mu \mathrm{m} 15 \mathrm{vol} \% \\
\text { composite }\end{array}$ & 5.0 & 0.59 & $\sqrt{ } \sqrt{ }$ & $\sqrt{ } \sqrt{ }$ & $\sqrt{ }$ & $\sqrt{ } \sqrt{ }$ & $\sqrt{ } \sqrt{ }$ & $\sqrt{ }$ \\
\hline
\end{tabular}


Table 3. Cont.

\begin{tabular}{|c|c|c|c|c|c|c|c|c|}
\hline \multirow{3}{*}{ Material } & \multirow{3}{*}{$\begin{array}{c}\text { Wear Rate } \\
\left(10^{-3} \mathrm{mM}^{3} / \mathrm{m}\right)\end{array}$} & \multirow{3}{*}{$\begin{array}{l}\text { Friction } \\
\text { Coefficient }\end{array}$} & \multicolumn{3}{|c|}{ Features } & \multirow{2}{*}{\multicolumn{3}{|c|}{ Wear Mechanisms ${ }^{1}$}} \\
\hline & & & $\begin{array}{l}\text { Worn } \\
\text { Surface }\end{array}$ & \multicolumn{2}{|c|}{ Wear Debris } & & & \\
\hline & & & Grooves & $\begin{array}{c}\text { Fine } \\
\text { Particles }\end{array}$ & Sheets & Abr & Oxi & Del \\
\hline $\begin{array}{c}10 \mu \mathrm{m} 10 \mathrm{vol} \% \\
\text { composite }\end{array}$ & 10.9 & 0.40 & $\sqrt{ }$ & $\sqrt{ } \sqrt{ }$ & $\sqrt{ } \sqrt{ }$ & $\sqrt{ }$ & $\sqrt{ } \sqrt{ }$ & $\sqrt{ } \sqrt{ }$ \\
\hline $\begin{array}{c}10 \mu \mathrm{m} 20 \mathrm{vol} \% \\
\text { composite }\end{array}$ & 13.3 & 0.44 & $\sqrt{ }$ & $\sqrt{ }$ & $\sqrt{ } \sqrt{ }$ & $\sqrt{ }$ & $\sqrt{ }$ & $\sqrt{ } \sqrt{ }$ \\
\hline
\end{tabular}

${ }^{1}$ Abr means abrasion; Oxi means oxidation; Del means delamination. ${ }^{2}$ The relative extent of every wear mechanism: $\sqrt{ }$ : slight; $\sqrt{ } \sqrt{ }$ : moderate; $\sqrt{ } \sqrt{ } \sqrt{ }$ : severe. ${ }^{3}$ The applied load was $20 \mathrm{~N}$ unless otherwise specified.

\subsubsection{Abrasion}

Grooves and scratches parallel to sliding direction on the worn surface are universally recognized as the evidence of abrasion wear, which are caused by hard particles or debris between the worn surfaces. For the composites in this study, grooves were widely observed. Maruschak et al. [36] quantitatively characterized the grooves (wear lines) via a digital image processing method. Here we simply described the extent of abrasion via SEM observation on the worn surface, namely, the morphology (width and depth) of grooves. As is shown in Table 3, the wear behavior of composite with coarse $(20 \mu \mathrm{m}) \mathrm{SiC}$ particles or tested at low applied load $(10 \mathrm{~N})$ was more inclined to be dominated by the abrasion mechanism.

\subsubsection{Oxidation}

Under atmospheric conditions, magnesium alloys are thermodynamically unstable [47]. Thus, dry sliding wear of magnesium alloys or composites results in formation of oxide film on the sliding surface. With the increase of thickness of oxide film to some critical thickness, the oxide film breaks and then a new oxide film form. This repeated wear process is oxidation wear and its wear rate is ordinarily slow [48]. As for magnesium alloys and composites, the oxide film is $\mathrm{MgO}$. As $\mathrm{MgO}$ film is loose, the break of $\mathrm{MgO}$ film give rise to the formation of fine granular debris (shown in Figure 7), which becomes the feature of oxidation [32,39]. As shown in Table 3, oxidation mechanism is dominated in composites with coarse $(20 \mu \mathrm{m})$ and low volume fraction $(10 \%)$ of $\mathrm{SiC}$ particles.

\subsubsection{Delamination}

As shown in Figure 5, delamination is always associated with plastic deformation on the surface and subsurface layer, and the sheet-like wear debris is the main characteristic for delamination [32]. With regard to the composites with necklace-type distribution of $\mathrm{SiC}$ particles, the bonding between matrix and $\mathrm{SiC}$ is usually not strong enough. This necklace distribution of $\mathrm{SiC}$ particles is caused by the "push" effect of solidification front. During the solidification of the composite, most SiC particles are pushed ahead of the solidification front while primary magnesium grains grow, so these particles are segregated in the intergranular regions during the impingement with other growing grains [19]. Moreover, particle segregation restricts the flow of $\mathrm{Mg}$ melts before the composite is completely solidified, and micro-cavities could be formed in these regions [19]. Therefore, the interface of $\mathrm{SiC}_{\mathrm{p}} / \mathrm{AZ91}$ composite fabricated by stir casting was weak and defective. Cracks are easy to be formed at the interface, and extend rapidly along the necklace, thus accelerating the development of delamination. Overall, as shown in Table 3, delamination was the dominant wear mechanism for the as-cast SiC/AZ91D composites with necklace-type distribution of SiC particles. Moreover, delamination tends to result in severe wear, deteriorating the wear resistance of composites drastically. 


\subsubsection{Transformation of Wear Mechanisms for the Composites}

As shown in Table 3, it is apparent that the wear mechanisms transformed with the variation of applied load, particle size and volume fraction of $\mathrm{SiC}$ particles. To be specific, the main wear mechanism transformed from abrasion to delamination with the increase of applied loads. The abrasion wear mechanism led to low wear rates, while delamination resulted in high wear rates. Therefore, the wear rate of composite increased with the increase of the applied loads. It could be speculated that there is a critical load value for the $10 \mu \mathrm{m} 15 \mathrm{vol} \%$ composite. When the applied load is lower than the critical load, $\mathrm{SiC}$ particles could improve the wear resistance of the composite, and if the load is higher than the critical load, $\mathrm{SiC}$ particles may degrade the wear resistance. The critical load might be related to the interface bonding between $\mathrm{SiC}$ particles and the matrix. In the present composites, owing to the weak interface bonding caused by the necklace-type particles distribution, the particles were pulled out from the matrix by the high shear stress when the applied loads exceeded the critical value, thus promoting delamination process. As for the particle size, it can be seen that the main wear mechanism changed from delamination to oxidation as the particle size increased from 5 to $20 \mu \mathrm{m}$. The SiC particles with average size of $20 \mu \mathrm{m}$ obviously stimulated the transition of dominated wear mechanisms to oxidation, which should be related with the particle distribution in the composites. With regard to volume fraction of $\mathrm{SiC}$ particles, its influence on wear mechanisms was similar to particles size. Higher content of $\mathrm{SiC}$ particles facilitates the formation of their necklace distribution, and increases the probability of debonding between $\mathrm{SiC}$ and the matrix, thus promoting the transformation of dominated wear mechanisms to delamination. Moreover, Table 3 lists the friction coefficient of various composites. The matrix exhibited the lowest friction coefficient of 0.32 , while the composites showed higher friction coefficients in the range of $0.39-0.59$, which might be resulted from the increased roughness of the surface owing to the introduction of large and hard particles. Furthermore, it can be seen that the friction coefficient increased with the decrease of applied load, as well as with the increase of size and contents of $\mathrm{SiC}$ particles in the composites.

In conclusion, it can be confirmed that the necklace distribution of $\mathrm{SiC}$ particles is detrimental to the wear resistance of the composites, which could accelerate the wear process via delamination mechanism. Since the degree of necklace distribution is alleviated to some extent, large particle size and low volume fraction of $\mathrm{SiC}$ particles could contribute to the improvement of wear resistance. As indicated in Table 3, the $20 \mu \mathrm{m} 15 \mathrm{vol} \% \mathrm{SiCp} / \mathrm{AZ} 91$ composite exhibit the optimal wear resistance under the load of $20 \mathrm{~N}$ and sliding speed of $0.8 \mathrm{~m} / \mathrm{s}$ for this study only. The advantages of this composite include low density $\left(1.998 \mathrm{~g} / \mathrm{cm}^{3}\right)$, low cost, and good wear resistance, which might be used in lightweight applications such as automotive and electronic industries. However, a major problem might exist for this composite. Since the main wear mechanism for this composite was oxidation, the surface (oxide film) degraded gradually with the prolonging of wear. Once the large $\mathrm{SiC}$ particles were pulled out from the matrix due to the degradation of surface or subsurface layer, and could not be expelled from the surfaces in time, they could accelerate the wear process by inducing a three-body abrasive wear or scratching the surface severely. Therefore, it's better to destroy the necklace-type distribution of $\mathrm{SiC}$ particles with further plastic deformation method, and investigate the wear behavior of composite with fine and dispersed $\mathrm{SiC}$ particles, which might endow the composite with simultaneous high wear resistance and strength. Our future study will focus on this perspective.

\section{Conclusions}

The dry sliding wear behaviors of various $\mathrm{SiC}$ particles reinforced AZ91D matrix composites were investigated. The main conclusions can be drawn as follows:

(1) The $\mathrm{SiC}$ particles exhibited typical necklace-type distribution in as-cast composites. Finer particle size and higher volume fraction of $\mathrm{SiC}$ particles promoted the formation of necklace distribution. At the lower load of $10 \mathrm{~N}$, the presence of $\mathrm{SiC}$ particles enhanced the wear resistance of $10 \mu \mathrm{m}$ $15 \mathrm{vol} \%$ composite, whose wear rate was $5.5 \times 10^{-3} \mathrm{mM}^{3} / \mathrm{m}$, much lower than that at high loads of 
$20 \mathrm{~N}\left(11.0 \times 10^{-3} \mathrm{mM}^{3} / \mathrm{m}\right)$ and $30 \mathrm{~N}\left(14.0 \times 10^{-3} \mathrm{mM}^{3} / \mathrm{m}\right)$. At higher applied loads, SiC particles were easy to debond from the matrix due to the weak interface bonding caused by necklace-type distribution, and the dominant wear mechanism transformed from abrasion to delamination.

(2) As the sizes of $\mathrm{SiC}$ particles increased from 5 to $20 \mu \mathrm{m}$, the wear rate of the composites decreased obviously because the necklace-type distribution became less evident. Especially, the $20 \mu \mathrm{m}$ $15 \mathrm{vol} \%$ composite exhibited the optimal wear resistance, as the dominated wear mechanism was converted from delamination to oxidation. Similarly, the necklace-type particle distribution became more evident with the increase of volume fractions of $\mathrm{SiC}$ particles, resulting in the higher wear rate of $13.3 \times 10^{-3} \mathrm{mM}^{3} / \mathrm{m}$ in the $10 \mu \mathrm{m} 20 \mathrm{vol} \%$ composite.

(3) Wear results showed that large particle size and low volume fraction of $\mathrm{SiC}$ particles could contribute to the improvement of wear resistance. The necklace-type distribution of $\mathrm{SiC}$ particles in as-cast composites are detrimental to enhancement of wear resistance, which should be avoided as it facilitated the operation of delamination during wear. Thus, subsequent plastic processing or modified casting methods are encouraged to promote the distribution of $\mathrm{SiC}$ particles and further improve the wear resistance.

Author Contributions: Conceptualization, X.W. and D.C.; data curation, C.S.; methodology, N.L. and X.H.; supervision, X.W.; writing-original draft, N.L. and X.W.; writing-review and editing, C.S. and H.L. All authors have read and agreed to the published version of the manuscript.

Funding: This work was supported by "National Natural Science Foundation of China" (Grant Nos. 51871074, 51971078 and 51671066) and "The Project National United Engineering Laboratory for Advanced Bearing Tribology, Henan University of Science and Technology" (Grant No. 201911).

Conflicts of Interest: The authors declare no conflict of interest.

\section{References}

1. Yin, S.Q.; Duan, W.C.; Liu, W.H.; Wu, L.; Yu, J.M.; Zhao, Z.L.; Liu, M.; Wang, P.; Cui, J.Z.; Zhang, Z.Q. Influence of specific second phases on corrosion behaviors of $\mathrm{Mg}-\mathrm{Zn}-\mathrm{Gd}-\mathrm{Zr}$ alloys. Corros. Sci. 2020, 166, 108419. [CrossRef]

2. Zhong, F.; Wu, H.J.; Jiao, Y.L.; Wu, R.Z.; Zhang, J.H.; Hou, L.G.; Zhang, M.L. Effect of Y and Ce on the microstructure, mechanical properties and anisotropy of as-rolled Mg-8Li-1Al alloy. J. Mater. Sci. Technol. 2020, 39, 124-134. [CrossRef]

3. Liu, H.; Huang, H.; Sun, J.P.; Wang, C.; Bai, J.; Ma, A.B.; Chen, X.H. Microstructure and mechanical properties of Mg-RE-TM cast alloys containing long period stacking ordered phases: A Review. Acta Metall. Sin. (Engl. Lett.) 2019, 32, 269-285. [CrossRef]

4. Tie, D.; Zhang, B.Y.; Yan, L.F.; Guan, R.G.; Ji, Z.S.; Liu, H.F.; Zhang, D.L.; Liu, D.B.; Chen, M.F. Rheological solidification behavior and mechanical properties of AZ91-Sn alloys. Crystals 2019, 9, 641. [CrossRef]

5. Liu, H.; Ju, J.; Yang, X.W.; Yan, J.L.; Song, D.; Jiang, J.H.; Ma, A.B. A two-step dynamic recrystallization induced by LPSO phases and its impact on mechanical property of severe plastic deformation processed $\mathrm{Mg}_{97} \mathrm{Y}_{2} \mathrm{Zn}_{1}$ alloy. J. Alloys Compd. 2017, 704, 509-517. [CrossRef]

6. Liu, H.; Huang, H.; Wang, C.; Sun, J.P.; Bai, J.; Xue, F.; Ma, A.B.; Chen, X.B. Recent advances in LPSO-containing wrought magnesium alloys: Relationships between processing, microstructure, and mechanical properties. JOM 2019, 71, 3314-3327. [CrossRef]

7. He, B.; Hu, Y.B.; Zhao, T.S.; Yao, Q.S.; Pan, F.S. Microstructure and mechanical properties of aged and hot rolled AZ80 magnesium alloy sheets. Crystals 2019, 9, 239. [CrossRef]

8. Wang, B.J.; Xu, D.K.; Wang, S.D.; Sheng, L.Y.; Zeng, R.C.; Han, E.H. Influence of solution treatment on the corrosion fatigue behavior of an as-forged Mg-Zn-Y-Zr alloy. Inter. J. Fatigue 2019, 120, 46-55. [CrossRef]

9. Huang, H.; Liu, H.; Wang, C.; Sun, J.P.; Bai, J.; Xue, F.; Jiang, J.H.; Ma, A.B. Potential of multi-pass ECAP on improving the mechanical properties of a high-calcium-content Mg-Al-Ca-Mn alloy. J. Magnes. Alloys 2019, 7, 617-627. [CrossRef]

10. Song, J.F.; She, J.; Chen, D.L.; Pan, F.S. Latest research advances on magnesium and magnesium alloys worldwide. J. Magnes. Alloys 2020, 8, 1-41. [CrossRef] 
11. Liu, W.Q.; Hu, X.S.; Wang, X.J.; Wu, K.; Zheng, M.Y. Evolution of microstructure, texture and mechanical properties of SiC/AZ31 nanocomposite during hot rolling process. Mater. Des. 2016, 93, 194-202. [CrossRef]

12. Shi, H.L.; Wang, X.J.; Zhang, C.L.; Li, C.D.; Ding, C. A novel melt processing for Mg matrix composites reinforced by multiwalled carbon nanotubes. J. Mater. Sci. Technol. 2016, 32, 1303-1308. [CrossRef]

13. Deng, K.; Li, J.; Xu, F.; Nie, K.; Liang, W. Hot deformation behavior and processing maps of fine-grained $\mathrm{SiC}_{\mathrm{p}} / \mathrm{AZ91}$ composite. Mater. Des. 2015, 67, 72-81. [CrossRef]

14. Zhou, S.; Deng, K.; Li, J.; Shang, S.; Liang, W.; Fan, J. Effects of volume ratio on the microstructure and mechanical properties of particle reinforced magnesium matrix composite. Mater. Des. 2014, 63, 672-677. [CrossRef]

15. Wang, X.J.; Xu, D.K.; Wu, R.Z.; Chen, X.B.; Peng, Q.M.; Jin, L.; Xin, Y.C.; Zhang, Z.Q.; Liu, Y.; Chen, X.H.; et al. What is going on in magnesium alloys? J. Mater. Sci. Technol. 2018, 34, 245-247. [CrossRef]

16. Deng, K.K.; Wang, C.J.; Nie, K.B.; Wang, X.J. Recent Research on the Deformation Behavior of Particle Reinforced Magnesium Matrix Composite: A Review. Acta Metall. Sin. (Engl. Lett.) 2019, 32, 413-425. [CrossRef]

17. Luo, A. Processing, microstructure, and mechanical-behavior of cast magnesium metal-matrix composites. Metall. Mater. Trans. A 1995, 26, 2445-2455. [CrossRef]

18. Zhong, W.M.; L'Espérance, G.; Suéry, M. Effect of thermomechanical processing on the microstructure and mechanical properties of $\mathrm{Al}-\mathrm{Mg}(5083) / \mathrm{SiC}_{\mathrm{p}}$ and $\mathrm{Al}-\mathrm{Mg}(5083) / \mathrm{Al}_{2} \mathrm{O}_{3}$ composites. Part 3: Fracture mechanisms of the composites. Mat. Sci. Eng. A 1996, 214, 104-114. [CrossRef]

19. Wang, X.J.; Wu, K.; Huang, W.X.; Zhang, H.F.; Zheng, M.Y.; Peng, D.L. Study on fracture behavior of particulate reinforced magnesium matrix composite using in situ SEM. Compos. Sci. Technol. 2007, 67, 2253-2260. [CrossRef]

20. García-Rodríguez, S.; Torres, B.; Maroto, A.; López, A.J.; Otero, E.; Rams, J. Dry sliding wear behavior of globular AZ91 magnesium alloy and AZ91/SiC $\mathrm{p}$ composites. Wear 2017, 390-391, 1-10. [CrossRef]

21. Venkataraman, B.; Sundararajan, G. The sliding wear behaviour of Al-SiC particulate composites-I. Macrobehaviour. Acta Mater. 1996, 44, 451-460. [CrossRef]

22. Iwai, Y.; Honda, T.; Miyajima, T.; Iwasaki, Y.; Surappa, M.K.; Xu, J.F. Dry sliding wear behavior of $\mathrm{Al}_{2} \mathrm{O}_{3}$ fiber reinforced aluminum composites. Compos. Sci. Technol. 2000,60, 1781-1789. [CrossRef]

23. Surappa, M.K.; Prasad, S.V.; Rohatgi, P.K. Wear and abrasion of cast Al-alumina particle composites. Wear 1982, 77, 295-302. [CrossRef]

24. Alpas, A.T.; Embury, J.D. Sliding and abrasive wear behavior of an aluminum (2014)-SiC particle reinforced composite. Scr. Mater. 1990, 24, 931-935. [CrossRef]

25. Kwok, J.; Lim, S.C. High-speed tribological properties of some $\mathrm{Al} / \mathrm{SiC}_{\mathrm{p}}$ composites: I. Frictional and wear-rate characteristics. Compos. Sci. Technol. 1999, 59, 55-63. [CrossRef]

26. Kwok, J.; Lim, S.C. High-speed tribological properties of some Al/SiCp composites: II. Wear mechanisms. Compos. Sci. Technol. 1999, 59, 65-75. [CrossRef]

27. Chung, S.; Hwang, B.H. A microstructural study of the wear behaviour of $\mathrm{SiC}_{\mathrm{p}} / \mathrm{Al}$ composites. Tribol. Int. 1994, 27, 307-314. [CrossRef]

28. Sato, A.; Mehrabian, R. Aluminum matrix composites: Fabrication and properties. Met. Trans. B 1976, 7, 443-451. [CrossRef]

29. Sannino, A.P.; Rack, H.J. Tribological investigation of 2009 Al-20 vol.\% SiC $/$ /17-4 PH Part I: Composite performance. Wear 1996, 197, 151-159. [CrossRef]

30. Skolianos, S.; Kattamis, T.Z. Tribological properties of $\mathrm{SiC}_{\mathrm{p}}$-reinforced $\mathrm{Al}-4.5 \% \mathrm{Cu}-1.5 \% \mathrm{Mg}$ alloy composites. Mat. Sci. Eng. A 1993, 163, 107-113. [CrossRef]

31. Das, S.; Das, S.; Das, K. Abrasive wear of zircon sand and alumina reinforced Al-4.5 wt $\% \mathrm{Cu}$ alloy matrix composites-A comparative study. Compos. Sci. Technol. 2007, 67, 746-751. [CrossRef]

32. Lim, C.Y.H.; Lim, S.C.; Gupta, A. Wear behaviour of $\mathrm{SiC}_{\mathrm{p}}$-reinforced magnesium matrix composites. Wear 2003, 255, 629-637. [CrossRef]

33. Alpas, A.T.; Zhang, J. Effect of SiC particulate reinforcement on the dry sliding wear of aluminum silicon alloys (A356). Wear 1992, 155, 83-104. [CrossRef]

34. Alpas, A.T.; Zhang, J. Wear rate transitions in cast aluminum-silicon alloys reinforced with $\mathrm{SiC}$ particles. Scr. Metall. Mater. 1992, 26, 505-509. [CrossRef] 
35. Hokkirigawa, K.; Kato, K. An experimental and theoretical investigation of plowing, cutting and wedge formation during abrasive wear. Tribol. Int. 1988, 21, 51-57. [CrossRef]

36. Maruschak, P.O.; Konovalenko, I.V.; Vuherer, T.; Panin, S.V.; Berto, F.; Danyliuk, I.M.; Menou, A. Analysis and automated fatigue damage evaluation of a 17Mn1Si pipeline steel. Procedia Struct. Integr. 2016, 2, 1928-1935. [CrossRef]

37. Suh, N.P. The delamination theory of wear. Wear 1973, 25, 111-124. [CrossRef]

38. Suh, N.P. An overview of the delamination theory of wear. Wear 1977, 44, 1-16. [CrossRef]

39. Taltavull, C.; Torres, B.; López, A.J.; Rams, J. Dry sliding wear behavior of AM60B magnesium alloy. Wear 2013, 301, 615-625. [CrossRef]

40. Karamis, M.B.; Cerit, A.A.; Selcuk, B.; Nair, F. The effects of different ceramics size and volume fraction on wear behavior of $\mathrm{Al}$ matrix composites (for automobile cam material). Wear 2012, 289, 73-81. [CrossRef]

41. Yilmaz, O.; Buytoz, S. Abrasive wear of $\mathrm{Al}_{2} \mathrm{O}_{3}$-reinforced aluminium-based mMCs. Compos. Sci. Technol. 2001, 61, 2381-2392. [CrossRef]

42. Gul, F.; Acilar, M. Effect of the reinforcement volume fraction on the dry sliding wear behaviour of $\mathrm{Al}-10 \mathrm{Si} / \mathrm{SiC} \mathrm{p}_{\mathrm{p}}$ composites produced by vacuum infiltration technique. Compos. Sci. Technol. 2004, 64, 1959-1970. [CrossRef]

43. Ma, T.J.; Yamaura, H.; Koss, D.A.; Voigt, R.C. Dry sliding wear behavior of cast SiC-reinforced Al mMCs. Mat. Sci. Eng. A 2003, 360, 116-125. [CrossRef]

44. Tjong, S.C.; Wu, S.Q.; Liao, H.C. Wear behaviour of an Al-12\% Si alloy reinforced with a low volume fraction of SiC particles. Compos. Sci. Technol. 1997, 57, 1551-1558. [CrossRef]

45. Iwai, Y.; Yoneda, H.; Honda, T. Sliding wear behavior of SiC whisker-reinforced aluminum composite. Wear 1995, 181, 594-602. [CrossRef]

46. Misra, A.; Finnie, I. A classification of three-body abrasive wear and design of a new tester. Wear 1980, 60, 111-121. [CrossRef]

47. Cui, X.H.; Wang, S.Q.; Wang, F.; Chen, K.M. Research on oxidation wear mechanism of the cast steels. Wear 2008, 265, 468-476. [CrossRef]

48. Sullivan, J.L.; Athwal, S.S. Mild wear of a low alloy steel at temperatures up to $500{ }^{\circ}$ C. Tribol. Int. 1983, 16, 123-131. [CrossRef] 